\title{
Resident or Present? Population Census Data Tell You More about Suburbanization
}

\author{
Kostas Rontos ${ }^{1}$, Andrea Colantoni ${ }^{2}$ [D, Luca Salvati ${ }^{3, *}$, Enrico Maria Mosconi ${ }^{4}(\mathbb{D}$ and \\ Antonio Giménez Morera 5 \\ 1 Department of Sociology, University of the Aegean, University Hill, EL-81100 Mitilini, Greece; \\ k.rontos@soc.aegean.gr \\ 2 Department of Agricultural and Forestry Sciences (DAFNE), Tuscia University, Via San Camillo de Lellis, \\ I-01100 Viterbo, Italy; colantoni@unitus.it \\ 3 Department of Economics and Law, University of Macerata, Via Armaroli 43, I-62100 Macerata, Italy \\ 4 Department of Economics, Engeneering, Society and Business, University of Tuscia, Via del Paradiso 47, \\ I-01100 Viterbo, Italy; enrico.mosconi@unitus.it \\ 5 Departamento de Economia y Ciencias Sociales, Universitat Politècnica de València, Cami de Vera S/N, \\ ES-46022 Valencia, Spain; angimo1@doctor.upv.es \\ * Correspondence: luca.salvati@unimc.it; Tel.: +39-06-615-710; Fax: +39-06-61-57-10-36
}

Received: 17 September 2020; Accepted: 6 October 2020; Published: 9 October 2020

\begin{abstract}
The present study analyzes population redistribution across metropolitan regions considering together changes over time in the spatial distribution of resident and present population from census data. Considering population dynamics in Athens, Greece, between 1991 and 2011, the results of this study evidenced how the ratio of present to resident population increases more rapidly in urban than rural areas along the last twenty years. By revealing different expansion processes at the regional and local scales, the present-to-resident ratio of usual population was correlated to selected variables (population density and growth, distance from the inner city and settlement dispersion) with the aim at delineating apparent and latent relationships with the local socioeconomic context. Statistical analysis indicates that the present-to-resident population ratio is reflective of the intense suburbanization observed until the early 1990s in Athens, determining population redistribution and settlement dispersion over larger areas.
\end{abstract}

Keywords: urban growth; population dynamics; indicator; multivariate analysis; Europe

\section{Introduction}

Cities all over the world are expanding rapidly to accommodate even growing demographic inflows [1-3]. However, a progressive shift toward population redistribution over larger regions and demographic change have characterized urban growth in advanced economies since the 1980s [4-6]. A millenary urban tradition and a complex dynamic of socio-demographic patterns makes the Mediterranean region a characteristic example of compact urban expansion with monocentric, dense settlement models [7-9]. However, these general patterns have been moved in the last few decades towards a more dispersed metropolitan expansion [10-12]. Suburbanization and population redistribution over larger spaces have been studied considering different indicators, methodologies and analysis scales [13-15]. However, earlier research has occasionally associated demographic dynamics with specific models of urban expansion, with the aim of delineating suburbanization trends [16-19].

Urban cycles were supposed to leverage socioeconomic disparities [20], widening (or containing) the spatial spread of (public and private) investments, human capital and infrastructures [21-23]. Additionally, demographic dynamics have consolidated territorial divides, fueling an asymmetric 
growth of dynamic and peripheral districts [24-27]. Structural demographic divides demonstrated to represent a direct outcome of polarized urban development coupled with persistent socio-spatial inequalities and divergences in population density [28-30]. In this perspective, population dynamics have been demonstrated to fuel the asymmetric expansion of dynamic fringe districts at the base of persistent suburbanization processes, typical of contemporary cities in Europe, and especially in Eastern and Southern peripheral countries [31-34].

In Mediterranean Europe, regional demographic dynamics have been demonstrated to reflect a structurally polarized economic development coupled with persistent social inequalities and divergences in population density and spatial distribution of settlements $[9,35,36]$. Depending on the heterogeneous impact of sequential urban waves at the local scale [37], the present study assumes that a spatial mismatch between present and resident population may indicate a latent settlement dispersion, reflecting the outcome of suburbanization [38-40]. More specifically, considering together the total amount of present and resident population in a given area, allows for deeper insights into settlement patterns and urbanization processes.

The incorporation of different definitions of population-showing a distinctive (e.g., temporary or permanent over time) relationship with the local context-allows for a refined interpretation of the empirical regularities between settlement expansion and socioeconomic processes characteristic of a high concentration of non-permanent population [41-43]. Strategies, alleviating the costs of excessive dispersion of population as a result of suburbanization, were proposed to consider the overall level of efficiency of the economic system, by developing a polycentric network of intermediate settlements attracting population and activities and promoting smaller-scale and less capital-intensive local economies [44-46]. Since comprehensive research and immediate policy response on the integrated management of suburban areas are still needed, our study contributes to a better understanding of the role of suburbanization in population distribution over space, informing policies that tackle the formidable challenges it poses [47-49].

With this perspective in mind, we assessed the spatio-temporal change in population considering two distinct demographic definitions (present and resident population) based on census data. We assume the spatial regime of resident and present population and their intrinsic change over time as a consequence of sequential waves of urbanization and suburbanization [49]. To verify this assumption, we correlated the two demographic indicators mentioned above with a set of predictors profiling socioeconomic contexts at the local scale in the Athens' Metropolitan Region (AMR) between 1991 and 2011, a period of intense suburbanization in the area [50]. This area was regarded as a paradigmatic example of the progressive change in the spatial regime of population distribution [51]. An improved knowledge of population dynamics allows for the investigation of selected socioeconomic characteristics of districts continuously attracting (or expelling) population [52-54]. Our findings finally clarify the role of metropolitan cycles (and, indirectly, economic downturns) in population redistribution at regional (and broader) scales.

\section{Methodology}

\subsection{Study Area}

The study area (Athens Metropolitan Region, AMR) expands more than $3000 \mathrm{~km}^{2}$ in the administrative region of Attica, Greece. While the study area mostly consists of mountain reliefs bordering the Greater Athens' settlements, Messoghia and Thriasio flat districts host most of the population settled around the central cities of Athens and Piraeus [55]. The spatial definition adopted in our study coincides with the physical boundaries of the Athens' "Urban Atlas" region [56] that includes (i) all mainland municipalities, and (ii) the municipalities of Salamina Island (Figure 1). According to the Greek administrative system promulgated in 2011 ("Kallikratis" law), we classified the AMR in 59 municipalities ("dimoi") including core urban municipalities (e.g., Athens and Piraeus), high-density municipalities belonging to the consolidated urban area and suburban "ring" municipalities (Figure 2). 
The empirical analysis encompasses a time window of 20 years between 1991 and 2011, covering the most recent dynamics of population and settlements in Athens and, more generally, in Greece [57].

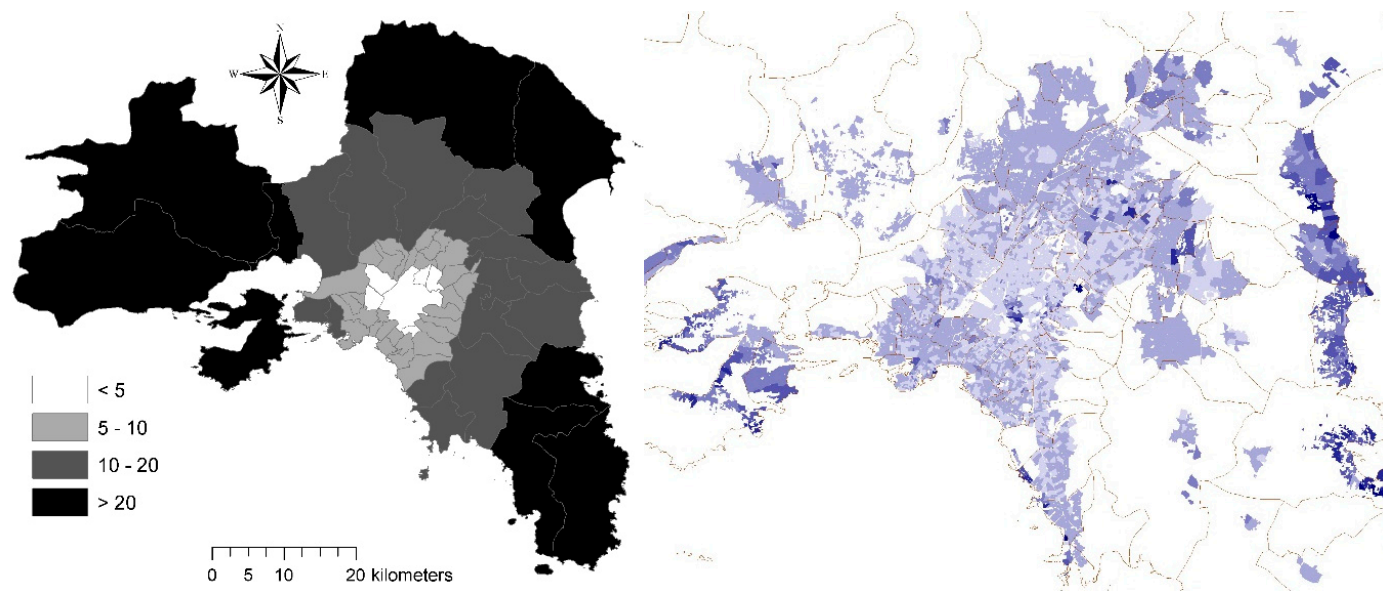

Figure 1. The boundaries of the study area by municipalities classified according to the distance to the inner city ( $\mathrm{km}$; left); a zoom of the Greater Athens' area illustrating the ratio of present-to-resident population at neighborhood level (right) (darker tones indicate a ratio $>1$ ).

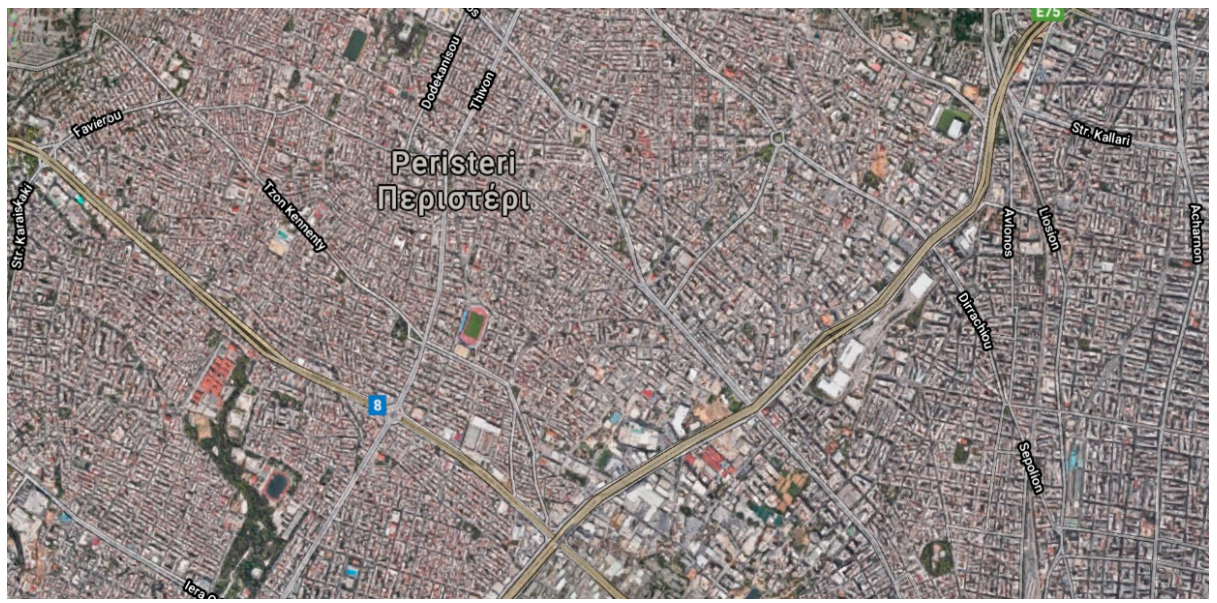

(a)

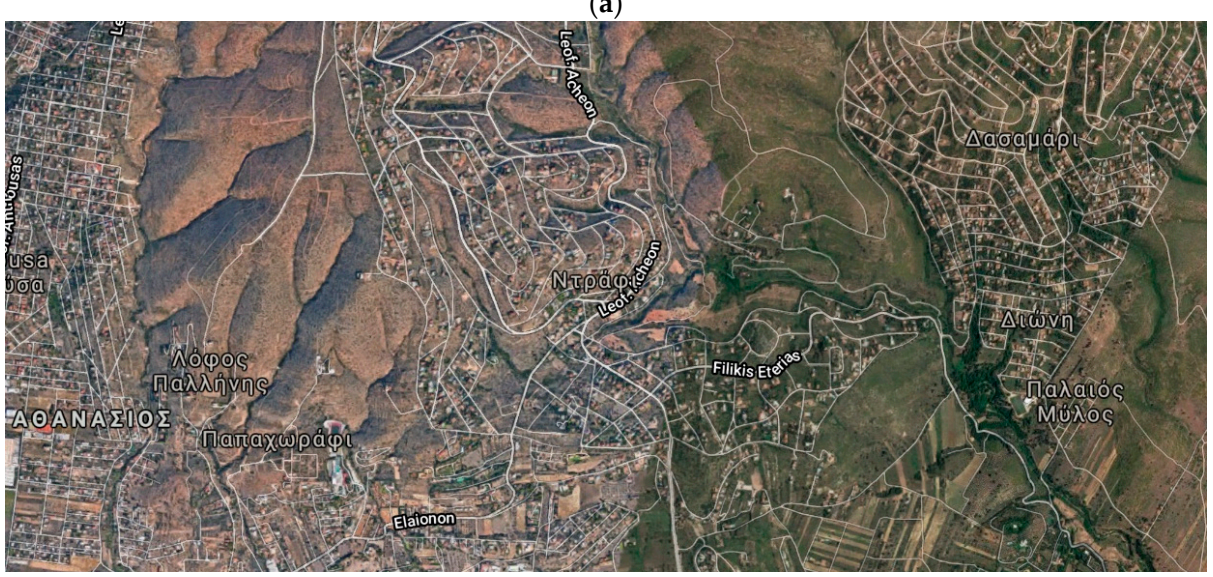

(b)

Figure 2. Urban fabric typical of the compact urbanization wave (between early 1950s and late 1970s, above picture (a)) and one resulting from suburbanization processes (between early 1980s and late 2000s, below picture (b)) in the Greater Athens (pictures derived from Google Earth imagery). 


\subsection{Demographic Data}

Three population definitions (usual resident population ("monimos plithismos"), de facto (or present) population ("pragmatikos plithismos") and registered population ("nomimos plitismou")) were adopted in the Greek censuses of population and households, in accordance with methodological principles as defined in the European Regulation 763/2008 in order to be used in population censuses in member states of the European Union (www.statistics.gr). Our study analyses the first two demographic aggregates. Total figures of population (both resident and present) were derived from population and household censuses (Greek Statistical Authority, ELSTAT). Density (per $\mathrm{km}^{2}$ ) and annual rate of population growth (\%) have been calculated by municipality and year. Municipal units allow for a refined analysis of changes in the spatial distribution of populations that may integrate information from different statistical sources [58].

Resident population includes the number of individuals who elect the usual residence in a given location (municipality, region) of the country at the date of population census [59]. The definition of "resident population" covers all the individuals-irrespective of citizenship (Greek native or foreigners) - declaring the place of their usual residence for at least 12 months before the census within a specific location of the Greek territory. Individuals settled in that location within the 12 months prior to the census date with the intention of remaining there for at least one year, were also included in the statistical aggregate of "resident population" [60]. Present (also known as "de facto") population refers to individuals declaring to be present at the census date in a given location in Greece. Population figures were thus determined through the elaboration of the single replies of the enumerated individuals regarding the place where they live, in accordance with the methodological principles defined in European Regulations (one of the most relevant for censuses is the 763/2008 act) extensively adopted in population censuses in the member states of the European Union.

In Greece, the 2011 census was carried out over three months (Spring 2011) using the usual resident criterion and asking for the place where individuals are present along that time period. The "de facto" criterion was instead adopted in the 1991 and 2001 censuses to enumerate individuals at a specific date (census day) and, at the same time, the usual residence of each respondent was asked and recorded. Based on these premises, since the 2011 census methodology presents some differences with those of earlier censuses $(1991,2001)$, we analyzed homogeneous data released by ELSTAT and reporting comparable resident and present population figures at the municipal level at the last three census years (1991, 2001 and 2011).

\subsection{Statistical Analysis}

Resident and present population were elaborated separately and a specific index (the absolute ratio of present-to-resident population) was built up in order to compare the two aggregates, with the final aim of identifying the intrinsic relationship between demographic dynamics, mechanisms of metropolitan expansion and the specific characteristics of the local context (Table 1). More specifically, the ratio of present-to-resident population was calculated at the beginning of the study period (1991) together with the percent change over time (1991-2011) in the same variable. The specific socioeconomic profiles of each municipality were determined considering four variables (population density, rate of population growth, percentage of adjacent buildings in total building stock, and the distance from downtown Athens) derived from official statistical sources that include the national census of population, households and buildings [61]. Following the operational indications of earlier studies [42], these variables provide a summary evaluation of the basic socioeconomic characteristics of each municipality in the study area, outlining (i) the role of agglomeration economies (population density), (ii) demographic dynamics resulting from both natural and migration balance), (iii) land-use (percentage of adjacent buildings, indicating compact or dispersed settlements), and (iv) accessibility (distance from Athens). 
Table 1. Ancillary variables considered in our study.

\begin{tabular}{ccc}
\hline \multicolumn{1}{c}{ Acronym } & Description & Source \\
\hline P-R & Ratio of present-to-resident population in 1991 & \\
\hline P-R' & Change in the ratio of present-to-resident population $(1991-2011)$ & Census of households \\
\hline \multicolumn{4}{c}{ Predictors } \\
\hline Density & Density of resident population in 1991 (inhabitants $\left./ \mathrm{km}^{2}\right)$ & Census of population \\
\hline Dynamics & Population growth rate (1991-2011), $\%$ & Census of population \\
\hline Adjacency & Adjacent buildings (\% share in total building stock) & Census of buildings \\
\hline Distance & Average distance from downtown Athens $(\mathrm{km})$ & ELSTAT cartography \\
\hline
\end{tabular}

A non-parametric analysis (using Spearman rank coefficients) assessing pair-wise (linear and non-linear) correlations between each of the above mentioned demographic indicators (dependent variable) and, separately, the above mentioned predictors were run for both indicators to verify their relationship with the background socioeconomic context [62]. Statistical significance was verified testing at $p<0.05$ after Bonferroni's correction for multiple comparison when appropriate [63]. Statistical analysis was refined with the results of multiple regressions that adopt a linear specification linking separately each of the two demographic indicators and the four socioeconomic predictors described above [64]. In line with the assumptions of our study, these models may clarify the sign and intensity of the relationship between population dynamics (based on the ratio between present and resident population settling in a given place) and specific waves of the urban cycle, with specific reference to suburbanization. All variables were standardized prior to multiple regression [65].

\section{Results}

Resident population in the Athens metropolitan region amounted to 3,490,186 inhabitants in 1991 and 3,751,710 inhabitants in 2011 ( $+0.35 \%$ by year). Present population grew from 3,562,233 inhabitants in 1991 to 3,792,256 inhabitants in 2011 ( $+0.30 \%$ per year). The ratio of present-to-resident population declined slightly from 1.02 in 1991 to 1.01 in 2011, suggesting that there is a small stock of non-resident population declaring to live in the study area, as typical of large metropolitan areas all over Europe (Figure 3).
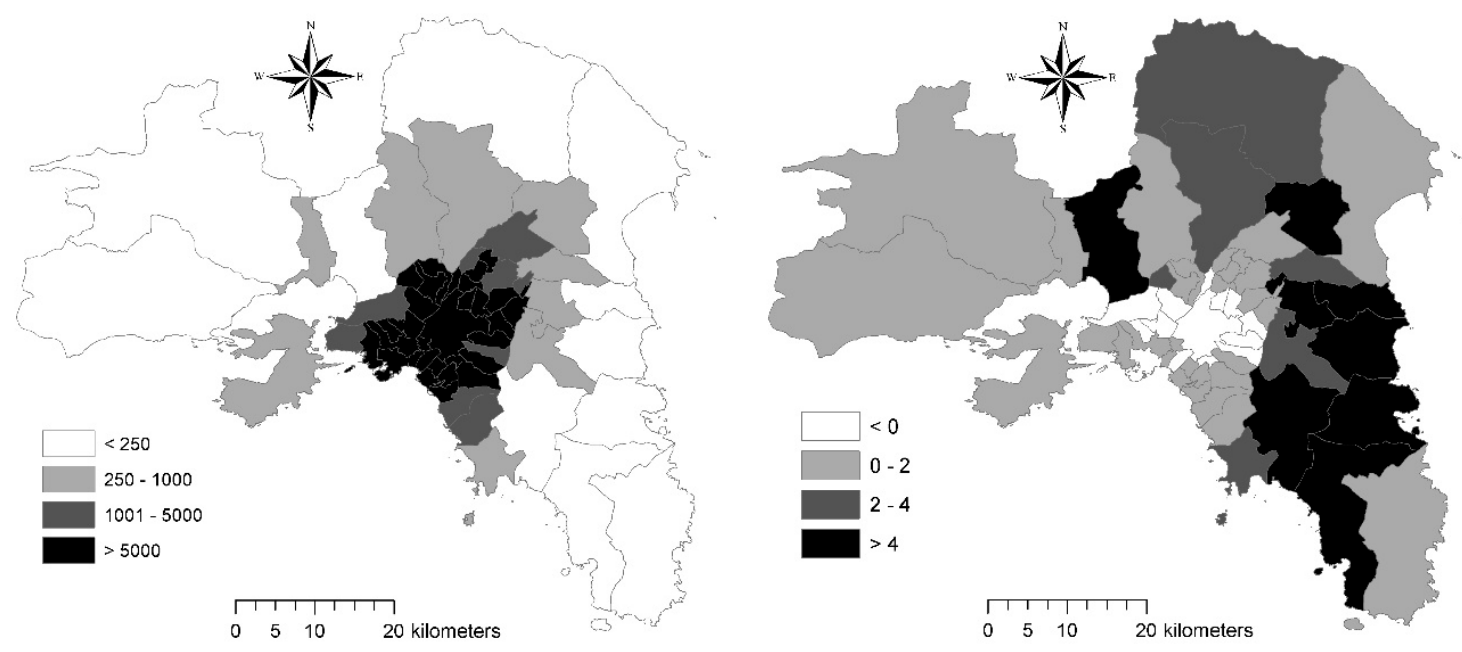

Figure 3. Density of resident population, 2011 (inhabitants $/ \mathrm{km}^{2}$; left) and annual population change (\%) between 1991 and 2011 (right) in the municipalities of the Athens' metropolitan region. 
The absolute ratio of present-to-resident population presents a relatively clear distribution over space at the beginning of the study period (1991), following the urban-rural gradient (Figure 4). Present population was moderately higher than resident population in both rural and suburban municipalities around Athens and the reverse pattern was observed in strictly urban locations of the Greater Athens' area. During the study period (1991-2011), resident population increased more rapidly than present population in strictly urban locations area (absolute ratio systematically $>1$ ), while decreasing in suburban municipalities. These findings suggest that suburbanization processes reflected an intense demographic change, mainly associated with a different intensity and spatial distribution of population dynamics.
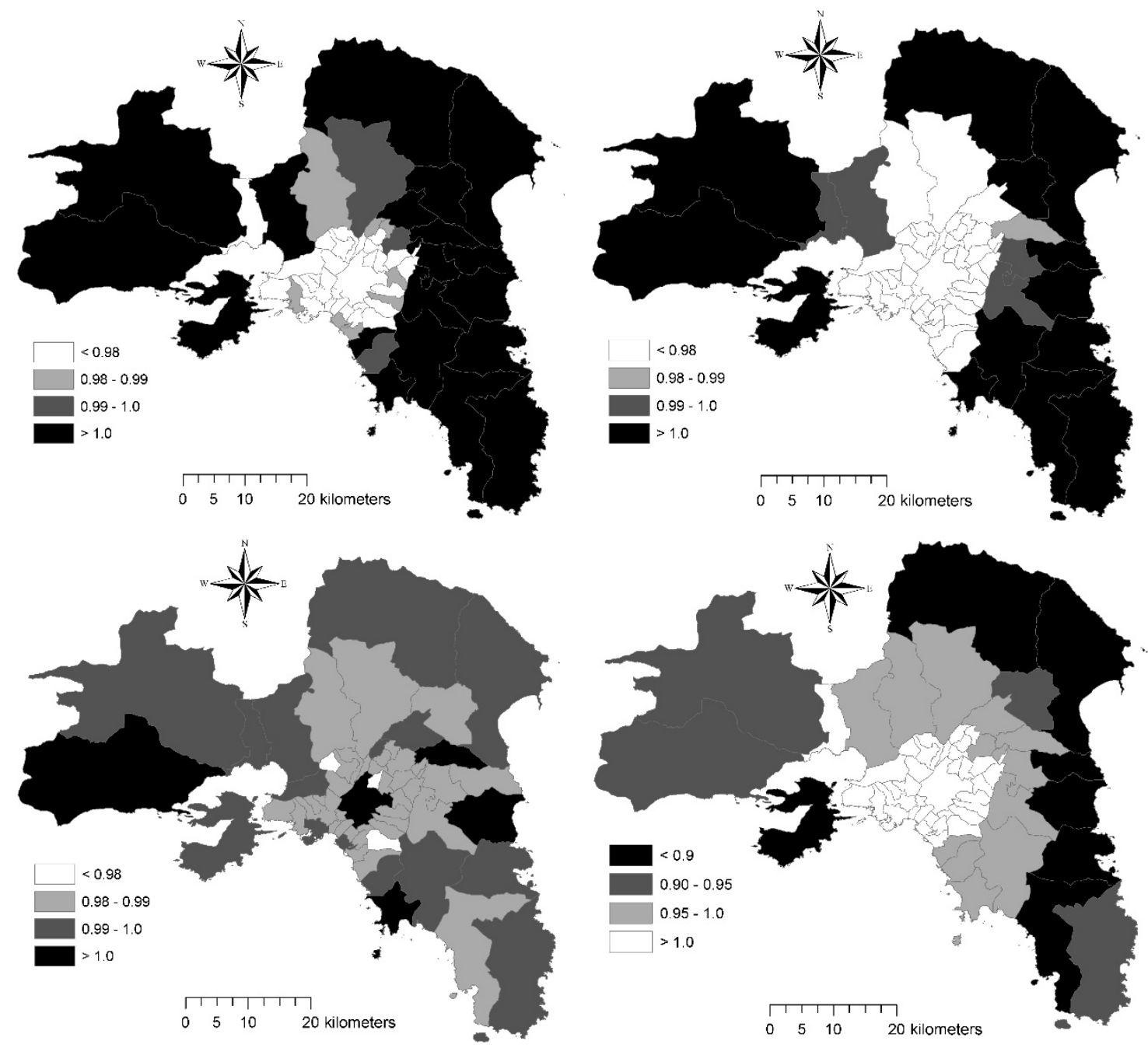

Figure 4. Relative change in the ratio of present-to-resident population over time in the municipalities of the Athens' metropolitan region (upper left: 1991; upper right: 2001; lower left: 2011; lower right: per cent change, 1991-2011).

Giving indication of the intensity and spatial direction of recent urban expansion, the annual rate of population increase during 1991-2011 distinguished urban from suburban municipalities according with the ratio of present-to-resident population. Figure 5 showed four groups of municipalities based on the distance from downtown Athens. The inner municipality of Athens clustered alone but relatively close to other strictly urban municipalities. On average, suburban municipalities experiencing intense urban expansion with marked population and settlement dispersion (prevalence of non-adjacent buildings) display a lower rate of change over time in the present-to-resident ratio than urban municipalities. 


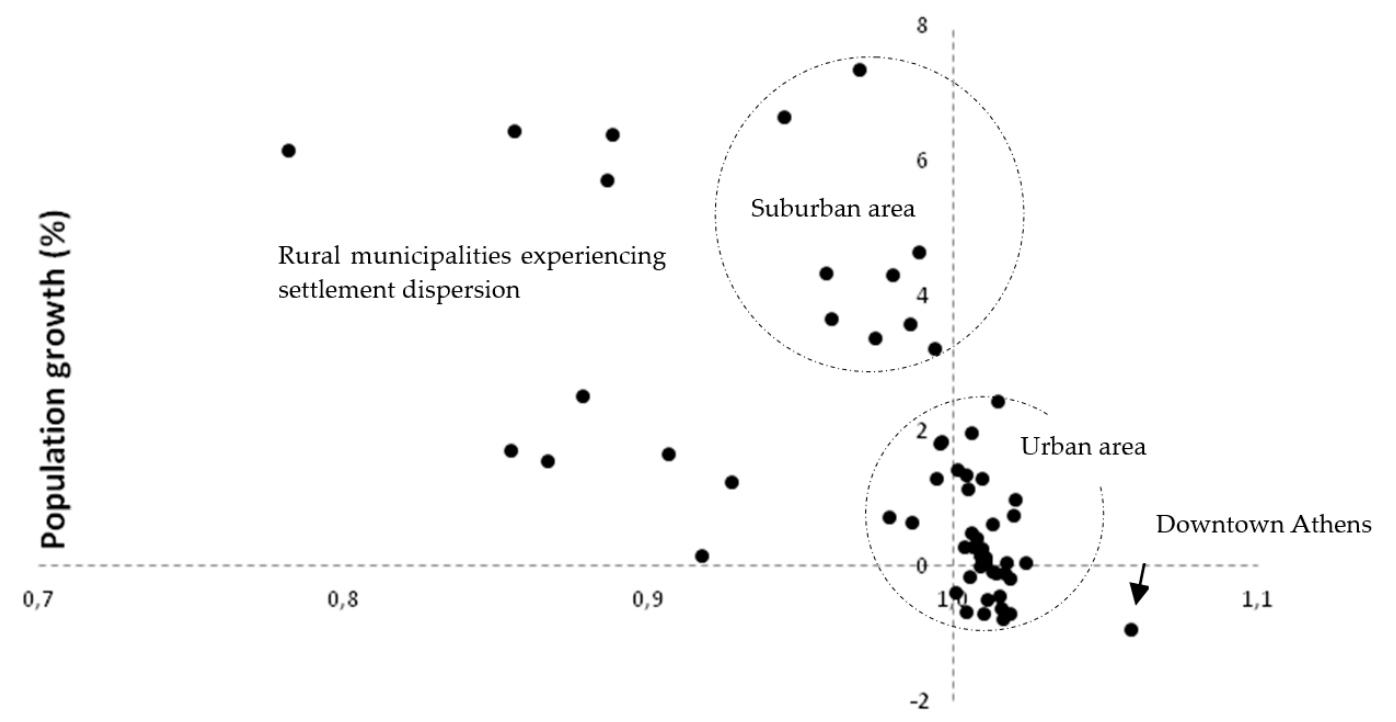

Change over time in the ratio of $\mathrm{P}$ to $\mathrm{R}$ population (1991-2011)

Figure 5. The relationship between annual per cent growth rate of resident population (1991-2011) and changes in the ratio of Present $(P)$ to Resident $(R)$ population (P-R') observed in the same period at the municipal scale in the study area.

A statistical analysis with independent variables was run to assess the intrinsic correlation between the ratio of present-to-resident population and the socioeconomic profile of municipalities in the study area, with the final aim at ascertaining apparent (and latent) processes of suburbanization (Table 2). Multiple regressions with four predictors of urban expansion, land-use, accessibility, and demographic characteristics were run for two dependent variables separately.

Table 2. Results of two separate multiple regression models for (a) the ratio of present-to-resident population at the beginning of the study period, 1991, and (b) the per cent change over time in the same ratio between 1991 and 2011 as dependent variables and the selected predictors describing the socioeconomic profile of each municipality in the study area.

\begin{tabular}{cccccc}
\hline Variable & $\boldsymbol{\beta}$ & St. Error & $\boldsymbol{t}$ & $\boldsymbol{p}$ & $\boldsymbol{r}_{\mathbf{s}}$ \\
\hline (a) Ratio of & present-to-resident & population, & 1991: & Adjusted $\mathrm{R}^{2}=0.68, \mathrm{~F}_{(4,54)}=31.9, p<0.001$ \\
Density & 0.133 & 0.117 & 1.14 & 0.26 & -0.83 \\
Dynamics & 0.037 & 0.122 & 0.30 & 0.76 & 0.63 \\
Adjacency & 0.521 & 0.142 & 3.68 & 0.00 & 0.86 \\
Distance & -0.441 & 0.180 & -2.45 & 0.02 & -0.83 \\
(b) Per cent & change over time & $(1991-2011)$ & in the ratio of present-to-resident population: \\
\multicolumn{7}{c}{ Density } & -0.155 & Adjusted R R $^{2}=0.71, \mathrm{~F}_{(4,54)}=32.7, p<0.001$ & & 0.78 \\
Dynamics & -0.278 & 0.109 & -1.42 & 0.03 & -0.74 \\
Adjacency & -0.599 & 0.123 & -2.26 & 0.00 & -0.77 \\
Distance & 0.213 & 0.128 & -4.67 & 0.23 & 0.82 \\
\hline
\end{tabular}

Based on data from 59 municipalities in the study area, linear regressions for both variables totalized high adjusted $R^{2}$ (0.68 and 0.71 , respectively for P-R and P-R'). The percent stock of adjacent buildings in total buildings (positively correlated with P-R) and the distance from downtown Athens (negatively correlated with P-R') were the most relevant predictors of the spatial variability in present and resident population at the beginning of the study period. Conversely, population growth (1991-2011) and the percent share of adjacent buildings in total building stock contributed significantly (with negative coefficients) to the spatial variation of P-R'. Results of non-parametric correlations confirm the outcomes of regression analysis, outlining how all predictors were (more or less intensively) 
associated with the two dependent variables, despite with a reverse sign. Taken together, these findings suggest how the spatial distribution of present and resident population transformed rapidly in the study area following suburbanization: non-resident (present) population was an effective discriminant of suburbanization processes, being higher in fringe locations with intense settlement expansion, mostly low- and medium-density.

\section{Discussion}

Our study investigates changes over time in the spatial pattern of present and resident population as a possible indicator of suburbanization in a Mediterranean region. These variables resulted to be (i) freely accessible from official statistics, (ii) comparable across regions and, in most cases, among countries, and (iii) reliable over relatively long time intervals when derived from homogenized population census time series [66-68]. The intrinsic relationship of demographic indicators with the socioeconomic profile of municipalities delineated recent urban transformations in the Athens' metropolitan region $[7,27,42]$. Correlation with factors of agglomeration, scale, accessibility, and amenities along the urban gradient is empirical evidence that population dynamics - more specifically, local-scale spatial differences between present and resident population-may delineate latent mechanisms of population redistribution over larger metropolitan regions [69-71]. These indicators may definitely reflect specific phases of the urban cycle, and especially suburbanization, better than other indicators [72].

Despite socioeconomic indicators being widely used in the analysis of suburbanization, demographic indicators seem to be especially appropriate to such issue [73-75]. Identifying similarities and differences in basic suburbanization processes following the spatial mismatch between present and resident population sheds light on metropolitan transformations under increasingly volatile business cycles [76-78]. Population mismatches in the study area were mostly reflected in the evident gap between downtown Athens and the rest of Attica, as a result of mono-centric urban growth [26]. In these regards, assuming the center-periphery polarization as a result of industrialization and consequent urbanization between 1940 and 1980, departures from mono-centric and compact growth models based on scale and agglomeration forces may reflect suburbanization processes (1980s-2010s), mirroring the progressive decline in density, infrastructural development and advanced economic functions as characteristic factors of growth [55]. A less intense mismatch between present and resident population-with total population being stable (or decreasing slightly) — was characteristic of medium-density settlements in such a context [13].

The recent crisis in Greece, and likely in other Mediterranean countries, has reshaped population geography toward a more intense polarization in attractive and depressed districts, corroborating the results of earlier studies [32,35]. The last recession was demonstrated to contribute to a generalized decrease in between-regions variability in population growth rates and to lower disparities in population density [79]. At the same time, recession determined an enlarged dichotomy in population density within rural, low-density regions, distinguishing internal, peripheral rural areas from accessible coastal districts and tourism-attractive locations [80], as sometimes observed in Spain [44] and Italy [81]. These dynamics have in some ways anticipated what was (and still is) observed in other Mediterranean regions, such as Portugal, Turkey, Cyprus and Southern France. More specifically, recession has delayed the intrinsic transformation of local economic structures, boosting the unemployment rate up to $25 \%$ in urban areas, with a particularly high rate of young unemployment, and exalting traditional socioeconomic divides [82-84].

A regional analysis of demographic transitions was revealed to be particularly appropriate in a context of changing socioeconomic relationships among relevant territorial actors [85-87]. More specifically, long-term population dynamics were influenced by a mix of socioeconomic processes reflecting supra-national forces and local factors of growth [88-90]. Being a sort of breakpoint in long-term population dynamics, the traditional urban-rural divide has transformed toward an increased polarization in high-density metropolitan (shrinking) regions and low-density, coastal and tourism-attractive (growing) districts, excluding few peripheral districts where depopulation and land 
abandonment remain the dominant evolutionary trajectory [91-93]. If such dynamics are demonstrated to be a common pattern in specific European macro-regions (especially with compact-dense settlements, such as Southern and Eastern Europe), a profound rethinking of regional development should lead to the design of policies oriented toward a stronger support of "intermediate" (peri-urban) territories representing the new engine of population growth [94,95]. In this regard, reconnecting demography to regional studies will definitely contribute to a more precise forecast of future socioeconomic trends in suburban areas, informing a spatially balanced and cohesive regional development [96]. Additional investigation will contribute to identify consensus criteria discriminating population dynamics in urban, rural and "intermediate" (suburban) districts based on the intrinsic evolution of the local socioeconomic context [97-100]. How much these dynamics can actually lead to latent mechanisms of spatial rebalancing is far from being clear [101-103]. More specifically, how much such population dynamics are generalizable to similar countries and macro-regions is an intriguing argument that requires further investigation [104].

\section{Conclusions}

Exploratory multivariate data techniques and regression models allow for an appropriate analysis of multifaceted spatial dynamics characterizing population growth in metropolitan regions, a sensitive indicator to urban cycles providing an indirect evaluation of short-term and medium-term socioeconomic transformations. An improved knowledge of population dynamics—considering different population definitions at census level, in turn reflecting distinctive linkages between population and space allows a refined investigation of suburbanization processes and the intrinsic socioeconomic characteristics associated with peri-urban districts attracting non-resident populations. In these regards, the empirical findings of this study clarify the role of urban cycles in the spatial redistribution of present and resident population at wider analysis scales, from regional to national levels, evidencing the spatial linkage between population and territory. By exalting traditional socioeconomic divides in Southern Europe, further studies should clarify the role of (i) the 2008 recession shaping recent processes of spatial re-distribution of population over larger metropolitan regions, going beyond suburbanization, and the importance of (ii) more recent demographic patterns related with the effect of the COVID pandemic in metropolitan areas, affecting population dynamics and indirectly determining urban shrinkage. The new population census wave, expected for the beginning of 2021 in the European countries, will provide the necessary database useful to test empirical hypotheses on such issues, evidencing the intrinsic transformation of local socioeconomic structures in metropolitan regions all over the continent.

Author Contributions: Conceptualization, L.S. and A.C.; methodology, K.R. and A.G.M.; software, E.M.M. and A.G.M.; validation, A.G.M.; formal analysis, A.C. and L.S.; investigation, K.R. and E.M.M.; resources, A.C. and E.M.M.; data curation, A.C. and A.G.M.; writing-original draft preparation, L.S. and K.R.; writing-review and editing, A.C., and E.M.M.; visualization, A.G.M.; supervision, A.G.M.; project administration, A.G.M. All authors have read and agreed to the published version of the manuscript.

Funding: This work received no funding.

Conflicts of Interest: The authors declare no conflict of interest.

\section{References}

1. Angel, S.; Parent, J.; Civco, D.L.; Blei, A.; Potere, D. The dimensions of global urban expansion: Estimates and projections for all countries, 2000-2050. Prog. Plan. 2011, 75, 53-107. [CrossRef]

2. Champion, A. Counterurbanisation: The Changing Pace and Nature of Population Decentralisation; Edward Arnold: London, UK, 1989.

3. Kabisch, N.; Haase, D. Diversifying European agglomerations: Evidence of urban population trends for the 21st century. Popul. Space Place 2011, 17, 236-253. [CrossRef] 
4. Haase, A.; Kabisch, S.; Steinführer, A.; Bouzarovski, S.; Hall, R.; Ogden, P. Emergent spaces of reurbanisation: Exploring the demographic dimension of inner-city residential change in a European setting. Popul. Space Place 2009, 16, 443-463. [CrossRef]

5. Couch, C.; Petschel-held, G.; Leontidou, L. Urban Sprawl in Europe: Landscapes, Land-Use Change and Policy; Blackwell: London, UK, 2007.

6. Catalàn, B.; Sauri, D.; Serra, P. Urban sprawl in the Mediterranean? Patterns of growth and change in the Barcelona Metropolitan Region 1993-2000. Landsc. Urban Plan. 2008, 85, 174-184.

7. Arapoglou, V.P.; Sayas, J. New facets of urban segregation in southern Europe-Gender, migration and social class change in Athens. Eur. Urban Reg. Stud. 2009, 16, 345-362. [CrossRef]

8. Çakir, G.; Ün, C.; Baskent, E.Z.; Kose, S.; Sivrikaya, F.; Keleş, S. Evaluating urbanization, fragmentation and land use/land cover change pattern in Istanbul city, Turkey from 1971 TO 2002. Land Degrad. Dev. 2008, 19, 663-675. [CrossRef]

9. Carlucci, M.; Chelli, F.M.; Salvati, L. Toward a New Cycle: Short-Term Population Dynamics, Gentrification, and Re-Urbanization of Milan (Italy). Sustainability 2018, 10, 3014. [CrossRef]

10. Ciommi, M.; Chelli, F.M.; Carlucci, M.; Salvati, L. Urban Growth and Demographic Dynamics in Southern Europe: Toward a New Statistical Approach to Regional Science. Sustainability 2018, 10, 2765. [CrossRef]

11. Delladetsima, P.M. The Emerging Property Development Pattern in Greece and its Impact on Spatial Development. Eur. Urban Reg. Stud. 2006, 13, 245-278. [CrossRef]

12. Kasanko, M.; Barredo, J.I.; Lavalle, C.; McCormick, N.; Demicheli, L.; Sagris, V.; Brezger, A. Are European Cities Becoming Dispersed? A Comparative Analysis of Fifteen European Urban Areas. Landsc. Urban Plan. 2006, 77, 111-130. [CrossRef]

13. Maloutas, T.; Siatitsa, D.; Balampanidis, D. Access to Housing and Social Inclusion in a Post-Crisis Era: Contextualizing Recent Trends in the City of Athens. Soc. Incl. 2020, 8, 5-15. [CrossRef]

14. Kroll, F.; Kabisch, N. The Relation of Diverging Urban Growth Processes and Demographic Change along an Urban-Rural Gradient. Popul. Space Place 2011, 18, 260-276. [CrossRef]

15. Van Criekingen, M. 'Gentrifying the re-urbanisation debate', not vice versa: The uneven socio-spatial implications of changing transitions to adulthood in Brussels. Popul. Space Place 2009, 16, 381-394. [CrossRef]

16. Chen, Y. Urban chaos and perplexing dynamics of urbanization. Lett. Spat. Resour. Sci. 2009, 2, 85-95. [CrossRef]

17. Benyaklef, M. Socio-economic disparities in the Mediterranean. Mediterr. Politics 1997, 2, 93-112. [CrossRef]

18. Maloutas, T. Social and spatial impact of the crisis in athens-from clientelist regulation to sovereign debt crisis. Région Développement 2014, 39, 149-166.

19. Gkartzios, M.; Scott, K. A Cultural Panic in the Province? Counterurban Mobilities, Creativity, and Crisis in Greece. Popul. Space Place 2015, 21, 843-855. [CrossRef]

20. Roberts, S. A Critical Evaluation of the City Life Cycle Idea. Urban Geogr. 1991, 12, 431-449. [CrossRef]

21. Pumain, D. Settlement systems in the evolution. Geogr. Ann. Ser. B Hum. Geogr. 2000, 82, 73-87. [CrossRef]

22. Salvati, L. Urban containment in action? Long-term dynamics of self-contained urban growth in compact and dispersed regions of southern Europe. Land Use Policy 2013, 35, 213-225. [CrossRef]

23. Maloutas, T. Social Segregation in Athens. Antipode 1993, 25, 223-239. [CrossRef]

24. Kandylis, G.; Maloutas, T.; Sayas, J. Immigration, inequality and diversity: Socio-ethnic hierarchy and spatial organization in Athens, Greece. Eur. Urban Reg. Stud. 2012, 19, 267-286. [CrossRef]

25. Bonifazi, C.; Heins, F. Testing the differential urbanisation model for Italy. Tijdschr. Econ. Soc. Geogr. 2003, 94, 23-37. [CrossRef]

26. Maloutas, T. Promoting social sustainability The case of Athens. City 2003, 7, 167-181. [CrossRef]

27. Lopez-Gay, A. Population growth and re-urbanization in Spanish inner cities: The role of internal migration and residential mobility. Quetelet J. 2014, 2, 67-92. [CrossRef]

28. Rontos, K. Demographic Trends, Young People's Attitudes towards Marriage and Socio-economic Changes Related to Family Formation in Greece and in the European Union: A Comparative Analysis Based on Official and Survey Research Data. Int. J. Econ. Bus. Adm. 2015, III, 11-33. [CrossRef]

29. Champion, T.; Hugo, G. New Forms of Urbanization; Informa UK Limited: Colchester, UK, 2017.

30. Gavalas, V.S.; Rontos, K.; Salvati, L. Who Becomes an Unwed Mother in Greece? Sociodemographic and Geographical Aspects of an Emerging Phenomenon. Popul. Space Place 2014, 20, 250-263. [CrossRef]

31. Gil-Alonso, F; Bayona-I-Carrasco, J.; Rúbies, I.P. From boom to crash: Spanish urban areas in a decade of change (2001-2011). Eur. Urban Reg. Stud. 2013, 23, 198-216. [CrossRef] 
32. Remoundou, K.; Gkartzios, M.; Garrod, G. Conceptualizing Mobility in Times of Crisis: Towards Crisis-Led Counterurbanization? Reg. Stud. 2015, 50, 1663-1674. [CrossRef]

33. Copus, A.; Melo, P.C.; Kaup, S.; Tagai, G.; Artelaris, P. Regional poverty mapping in Europe-Challenges, advances, benefits and limitations. Local Econ. 2015, 30-38. [CrossRef]

34. Connaughton, J.E. Local Economic Impact of the Great Recession of 2008/2009. RRS 2010, 40, 1-4.

35. Tapia, F.J.B.; Díez-Minguela, A.; Martinez-Galarraga, J. Tracing the Evolution of Agglomeration Economies: Spain, 1860-1991. J. Econ. Hist. 2018, 78, 81-117. [CrossRef]

36. Gkartzios, M. 'Leaving Athens': Narratives of counterurbanisation in times of crisis. J. Rural. Stud. 2013, 32, 158-167. [CrossRef]

37. Goerlich, L.; Mas, M. La concentration spatiale de la population espagnole de 1900 à 2001: Confirmations empiriques. Population 2008, 63, 731-745. [CrossRef]

38. Lerch, M. The Role of Migration in the Urban Transition: A Demonstration from Albania. Demography 2014, 51, 1527-1550. [CrossRef] [PubMed]

39. Camagni, R.; Capello, R.; Caragliu, A. Static vs. dynamic agglomeration economies. Spatial context and structural evolution behind urban growth. Pap. Reg. Sci. 2015, 95, 133-158. [CrossRef]

40. Dyson, T. The role of the demographic transition in the process of urbanization. Popul. Dev. Rev. 2011, 37, 34-54. [CrossRef] [PubMed]

41. Ciommi, M.; Chelli, F.M.; Salvati, L. Integrating parametric and non-parametric multivariate analysis of urban growth and commuting patterns in a European metropolitan area. Qual. Quant. 2019, 53, 957-979. [CrossRef]

42. Reynaud, C.; Miccoli, S.; Benassi, F.; Naccarato, A.; Salvati, L. Unravelling a demographic 'Mosaic': Spatial patterns and contextual factors of depopulation in Italian Municipalities, 1981-2011. Ecol. Indicat. 2020, 115, 106356. [CrossRef]

43. Panori, A.; Ballas, D.; Psycharis, Y. SimAthens: A spatial microsimulation approach to the estimation and analysis of small area income distributions and poverty rates in the city of Athens, Greece. Comput. Environ. Urban Syst. 2017, 63, 15-25. [CrossRef]

44. Garcia, S. The Breakdown of the Spanish Urban Growth Model: Social and Territorial Effects of the Global Crisis. Int. J. Urban Reg. Res. 2010, 34, 967-980. [CrossRef]

45. González-Pérez, J.M. The Real Estate and Economic Crisis: An Opportunity for Urban Return and Rehabilitation Policies in Spain. Sustainability 2010, 2, 1571-1601. [CrossRef]

46. Combes, P.-P.; Duranton, G.; Gobillon, L. The identification of agglomeration economies. J. Econ. Geogr. 2011, 11, 253-266. [CrossRef]

47. Maloutas, T. Segregation, Social Polarization and Immigration in Athens during the 1990s: Theoretical Expectations and Contextual Difference. Int. J. Urban Reg. Res. 2007, 31, 733-758. [CrossRef]

48. Lerch, M. Internal and International Migration Across the Urban Hierarchy in Albania. Popul. Res. Policy Rev. 2016, 35, 851-876. [CrossRef] [PubMed]

49. Storper, M. Why do regions develop and change? The challenge for geography and economics. J. Econ. Geogr. 2010, 11, 333-346. [CrossRef]

50. Frick, S.A.; Rodríguez-Pose, A. Change in urban concentration and economic growth. World Dev. 2018, 105, 156-170. [CrossRef]

51. Chorianopoulos, I.; Tsilimigkas, G.; Koukoulas, S.; Balatsos, T. The shift to competitiveness and a new phase of sprawl in the Mediterranean city: Enterprises guiding growth in Messoghia-Athens. Cities 2014, 39, 133-143. [CrossRef]

52. Panori, A.; Psycharis, Y.; Ballas, D. Spatial segregation and migration in the city of Athens: Investigating the evolution of urban socio-spatial immigrant structures. Popul. Space Place 2018, 25, e2209. [CrossRef]

53. Bonavero, P.; Sforzi, F.; Dematteis, G. The Italian Urban System: Towards European Integration; Routledge: London, UK, 2009.

54. Souliotis, N. Cultural economy, sovereign debt crisis and the importance of local contexts: The case of Athens. Cities 2013, 33, 61-68. [CrossRef]

55. Petrakos, G.C. Urban Concentration and Agglomeration Economies: Re-examining the Relationship. Urban Stud. 1992, 29, 1219-1229. [CrossRef]

56. Salvati, L.; Ferrara, A.; Chelli, F. Long-term growth and metropolitan spatial structures: An analysis of factors influencing urban patch size under different economic cycles. Geogr. Tidsskr. J. Geogr. 2017, 118, 56-71. [CrossRef] 
57. European Environment Agency. Mapping Guide for a European Urban Atlas; EEA: Copenhagen, Denmark, 2010.

58. Monastiriotis, V. Examining the consistency of spatial association patterns across socio-economic indicators: An application to the Greek regions. Empir. Econ. 2008, 37, 25-49. [CrossRef]

59. Pacione, M. Urban Geography: A Global Perspective; Routledge: London, UK, 2005.

60. Rosti, L.; Chelli, F. Self-employment among Italian female graduates. Educ. Train. 2009, 51, 526-540. [CrossRef]

61. Rosti, L.; Chelli, F. Higher education in non-standard wage contracts. Educ. Train. 2012, 54, 142-151. [CrossRef]

62. Gigliarano, C.; Chelli, F.M. Measuring inter-temporal intragenerational mobility: An application to the Italian labour market. Qual. Quant. 2016, 50, 89-102. [CrossRef]

63. Chelli, F.; Gigliarano, C.; Mattioli, E. The Impact of Inflation on Heterogeneous Groups of Households: An Application to Italy. Econ. Bull. 2009, 29, 1276-1295.

64. Chelli, F.M.; Ciommi, M.; Emili, A.; Gigliarano, C.; Taralli, S. Assessing the Equitable and Sustainable Well-Being of the Italian Provinces. Int. J. Uncertain. Fuzziness Knowl. Based Syst. 2016, 24, 39-62. [CrossRef]

65. Chelli, F.; Rosti, L. Age and gender differences in Italian workers' mobility. Int. J. Manpow. 2002, 23, 313-325. [CrossRef]

66. Maloutas, T. Contextual Diversity in Gentrification Research. Crit. Sociol. 2011, 38, 33-48. [CrossRef]

67. Lamonica, G.R.; Chelli, F.M. The performance of non-survey techniques for constructing sub-territorial input-output tables. Pap. Reg. Sci. 2018, 97, 1169-1202. [CrossRef]

68. Ciommi, M.; Gigliarano, C.; Emili, A.; Taralli, S.; Chelli, F.M. A new class of composite indicators for measuring well-being at the local level: An application to the Equitable and Sustainable Well-being (BES) of the Italian Provinces. Ecol. Indic. 2017, 76, 281-296. [CrossRef]

69. Salvati, L.; Lamonica, G.R. Containing urban expansion: Densification vs greenfield development, socio-demographic transformations and the economic crisis in a Southern European City, 2006-2015. Ecological Indicators 2020, 110, 105923. [CrossRef]

70. Aplerovich, G. An empirical study of population, density gradients and their determinants. J. Reg. Sci. 1983, 23, 529-540.

71. Carson, D.B.; Carson, D.A.; Porter, R.; Ahlin, C.Y.; Sköld, P. Decline, Adaptation or Transformation: New Perspectives on Demographic Change in Resource Peripheries in Australia and Sweden. Comp. Popul. Stud. 2016, 41.

72. Bosker, M. Growth, Agglomeration and Convergence: A Space-time Analysis for European Regions. Spat. Econ. Anal. 2007, 2, 91-100. [CrossRef]

73. Davies, S. Regional resilience in the 2008-2010 downturn: Comparative evidence from European countries. Camb. J. Reg. Econ. Soc. 2011, 4, 369-382. [CrossRef]

74. Billari, F.C.; Kohler, H.-P. Patterns of low and lowest-low fertility in Europe. Popul. Stud. 2004, 58, 161-176. [CrossRef]

75. Peck, J. Austerity urbanism. City 2012, 16, 626-655. [CrossRef]

76. Reher, D.S. Economic and Social Implications of the Demographic Transition. Popul. Dev. Rev. 2011, 37, 11-33. [CrossRef]

77. Fuchs, R.J.; Demko, G.J. Rethinking population distribution policies. Popul. Res. Policy Rev. 1983, 2, 161-187. [CrossRef]

78. Klasen, S.; Nestmann, T. Population, population density and technological change. J. Popul. Econ. 2006, 19, 611-626. [CrossRef]

79. Monastiriotis, V. Making geographical sense of the Greek austerity measures: Compositional effects and long-run implications. Camb. J. Reg. Econ. Soc. 2011, 4, 323-337. [CrossRef]

80. Palloni, A.; Tienda, M. Demographic Responses to Economic Recessions in Latin America Since 1900. Sociol. Inq. 1992, 62, 246-270. [CrossRef]

81. Koutsampelas, C.; Tsakloglou, P. The distribution of full income in Greece. Int. J. Soc. Econ. 2013, 40, 311-330. [CrossRef]

82. Cecchini, M.; Zambon, I.; Salvati, L. Housing and the city: A spatial analysis of residential building activity and the socio-demographic background in a Mediterranean city, 1990-2017. Sustainability 2019, 11, 375. [CrossRef]

83. Lusardi, A.; Schneider, D.; Tufano, P. The Economic Crisis and Medical Care Use: Comparative Evidence from Five High-Income Countries. Soc. Sci. Q. 2014, 96, 202-213. [CrossRef] 
84. Stuckler, D.; Reeves, A.; Karanikolos, M.; McKee, M. The health effects of the global financial crisis: Can we reconcile the differing views? A network analysis of literature across disciplines. Health Econ. Policy Law 2014, 10, 83-99. [CrossRef]

85. Simou, E.; Koutsogeorgou, E. Effects of the economic crisis on health and healthcare in Greece in the literature from 2009 to 2013: A systematic review. Health Policy 2014, 115, 111-119. [CrossRef]

86. Li, Z.; Cheng, J.; Wu, Q.Y. Analyzing regional economic development patterns in a fast developing province of China through geographically weighted principal component analysis. Lett. Spat. Resour. Sci. 2015, 9, 233-245. [CrossRef]

87. Rodríguez-Pose, A.; Fratesit, U. Between Development and Social Policies: The Impact of European Structural Funds in Objective 1 Regions. Reg. Stud. 2004, 38, 97-113. [CrossRef]

88. Schneider, D. The Great Recession, Fertility, and Uncertainty: Evidence from the United States. J. Marriage Fam. 2015, 77, 1144-1156. [CrossRef]

89. Stockdale, A. Contemporary and 'Messy' Rural In-migration Processes: Comparing Counterurban and Lateral Rural Migration. Popul. Space Place 2015, 22, 599-616. [CrossRef]

90. Dijkstra, L.; Garcilazo, E.; McCann, P. The effects of the global financial crisis on European regions and cities. J. Econ. Geogr. 2015, 15, 935-949. [CrossRef]

91. Berg, M.V.D. City Children and Genderfied Neighbourhoods: The New Generation as Urban Regeneration Strategy. Int. J. Urban Reg. Res. 2012, 37, 523-536. [CrossRef]

92. Kulu, H.; Boyle, P.J.; Andersson, G. High Suburban Fertility: Evidence from Four Northern European Countries. Demogr. Res. 2009, 21, 915-944. [CrossRef]

93. Walford, N.S.; Kurek, S. Outworking of the Second Demographic Transition: National Trends and Regional Patterns of Fertility Change in Poland, and England and Wales, 2002-2012. Popul. Space Place 2015, 22, 508-525. [CrossRef]

94. Dyson, T. On Demographic and Democratic Transitions. Popul. Dev. Rev. 2013, 38, 83-102. [CrossRef]

95. Tapinos, G.; Mason, A.; Bravo, J. Demographic Responses to Economic Adjustment in Latin America; Oxford University Press: Oxford, UK; New York, NY, USA, 1997.

96. Cechella, C.; Dentinho, T.P.; Silva, J.R. World centralities for political, demographic and market purposes. Lett. Spat. Resour. Sci. 2011, 5, 73-83. [CrossRef]

97. Del Bono, E.; Weber, A.; Winter-Ebmer, R. Fertility and economic instability: The role of unemployment and job displacement. J. Popul. Econ. 2014, 28, 463-478. [CrossRef]

98. Copus, A.; Mantino, F.; Noguera, J. Inner Peripheries: An oxymoron or a real challenge for territorial cohesion? Ital. J. Plan. Pract. 2017, 7, 24-49.

99. Lesthaeghe, R.J.; Neidert, L. The Second Demographic Transition in the United States: Exception or Textbook Example? Popul. Dev. Rev. 2006, 32, 669-698. [CrossRef]

100. Wheaton, W.C.; Shishido, H. Urban Concentration, Agglomeration Economies, and the Level of Economic Development. Econ. Dev. Cult. Chang. 1981, 30,17-30. [CrossRef]

101. Işık, O.; Pinarcioğlu, M.M. Geographies of a silent transition: A geographically weighted regression approach to regional fertility differences in Turkey. Eur. J. Popul. 2007, 22, 399-421. [CrossRef]

102. Cherlin, A.; Cumberworth, E.; Morgan, S.P.; Wimer, C. The Effects of the Great Recession on Family Structure and Fertility. Ann. Am. Acad. Political Soc. Sci. 2013, 650, 214-231. [CrossRef]

103. Goldstein, J.; Örsal, D.D.K.; Kreyenfeld, M.; Jasilioniene, A. Fertility Reactions to the "Great Recession " in Europe. Demogr. Res. 2013, 29, 85-104. [CrossRef]

104. Lee, K.O.; Painter, G. What happens to household formation in a recession? J. Urban Econ. 2013, 76, 93-109. [CrossRef]

(C) 2020 by the authors. Licensee MDPI, Basel, Switzerland. This article is an open access article distributed under the terms and conditions of the Creative Commons Attribution (CC BY) license (http://creativecommons.org/licenses/by/4.0/). 